\title{
"Mais um belo modelo da nova geração que a Educação Física está construindo no Brasil": sadio, forte, belo e branco
}

https://doi.org/10.11606/issn.1981-4690.v35i1p95-107

\author{
André Luiz dos Santos Silva* \\ J éferson Luís Staudt*
}

*Universidade Federal do Rio Grande do

Sul, Porto Alegre, RS, Brasil.

**Universidade

Feevale, Novo Hamburgo, RS,

Brasil.

Este artigo analisa a ausência do corpo negro nas representações de beleza masculina construídas pela revista Educação Physica, entre 1939 e 1944, período em que a direção técnica do periódico ficou ao cargo de Hollanda Loyola, renomado professor e integrante da Ação Integralista Brasileira. 0 debate proposto pela revista teria produzido representações reguladoras do corpo masculino, pautadas em concepções morais e legitimadas por argumentos científicos, sustentando a ideia de beleza enquanto atributo próprio dos corpos brancos. Como efeito, possiveis representações de beleza negra foram impensadas, elegendo como representantes homens brancos, trabalhadores, fortes, pais de familia, capazes de gerar o futuro próspero para o Brasil, seja via força de trabalho ou pela formação de uma prole sã. Sob a intenção de se construir a imagem de um país homogêneo, fez-se necessário tornar menos evidente a diversidade política, cultural e étnico-racial como forma de construir uma identidade nacional, assim, a revista coloca à margem os "homens de cor" e todos aqueles que se distanciam da centralidade dos corpos brancos.

Palavras-chave: Revista Educação Physica; Hollanda Loyola; Beleza masculina; Corpo negro.

\section{Introdução}

Este texto aborda as representaçóes de beleza masculina e suas relaçóes com o corpo negro nas ediçóes da Revista Educação Physica, entre 1939 e 1944, período em que Hollanda Loyola ocupou o cargo de diretor técnico ${ }^{1}$. Renomado professor de Educação Física, Loyola foi um importante colaborador do periódico desde sua primeira edição, em $1932^{3, a}$. Enquanto diretor técnico, teria contribuído para ampliação do volume, assim como para a estabilização de sua periodicidade, até então inconstante no número de ediçóes e textos publicados.

Politicamente, Hollanda Loyola esteve vinculado à Ação Integralista Brasileira (AIB) ${ }^{4, b}$, movimento de extrema direita criado em 1932, no qual exerceu a funçáo de Mestre de Campo da Milícia no Distrito Federal (RJ). De inspiraçâo fascista, a AIB defendia concepçôes de raça e identidade nacional, elementos fundamentais para seu projeto político, que concebia a reconstrução nacional por meio da solução do "problema racial". Tais ideais náo eram propagandeados exclusivamente pela Ação Integralista Brasileira, constituindo-se como elementos fundamentais à proposta de nacionalismo do Governo Vargas (1930-1945)c.

Concebida como uma população sem um perfil étnico, viciosa, incapaz para o trabalho, vadia e incivilizada, urgia regenerá-la por meio de investimentos em diversos campos, dentre os quais: a saúde, a educação e o urbanismo. Desse modo, questóes como unidade nacional, disciplina e organização racional do trabalho, tão importantes para o governo, passam a interferir no fazer de educadores, médicos, juristas, arquitetos, etc ${ }^{5,6}$.

Áreas correlatas à Educação passam a ser vistas como salvaguardas da "causa cívica", atuando em vistas à saúde, ao disciplinamento e à capacidade de trabalho ${ }^{6}$. Em decorrência disso, na década de 1930, a Educação Física ganha evidência e representatividade em diversas instâncias, dentre as quais: criação dos primeiros cursos de formaçáo, obrigatoriedade nas escolas de todo Brasil, referências nos documentos constitucionais de 1934 e 1937, assim como a publicação de periódicos especializados 5 .

Com a implantação do Estado Novo (1937-1945), 
características ditatoriais intensificam-se no projeto de governo de Getúlio Vargas, que, sob o argumento de defesa nacional de uma ameaça comunista, dissolve o Congresso e implementa uma nova constituição de inspiração polonesa e tendências marcadamente fascistas. Em meio às medidas tomadas pelo Estado Novo, ocorre a dissolução dos partidos políticos, dentre eles, a Ação Integralista Brasileira, que sofre uma série de reformulaçóes para manter suas funçôes. Assim, a AIB transforma-se em uma sociedade civil organizada: Associação Brasileira de Cultura (ABC) - extinta em 1938, tendo alguns de seus líderes exilados. Hollanda Loyola teria, então, se desvinculado da AIB/ABC e, em 1939, assumido a direção técnica da Revista Educação Physica, cargo que ocupou até 1944, ano de seu falecimento ${ }^{7}$.

Em um período em que raça, povo e nação eram entendidos quase como sinônimos, a estética corporal e os marcadores raciais poderiam sinalizar o progresso nacional assim como o seu subdesenvolvimento. Desse modo, se o aperfeiçoamento estético/racial refletia o avanço da

\section{Método}

Para a realização deste estudo, foram acessados todos os exemplares da Revista Educação Physica compreendidos entre as ediçóes 34, de setembro de 1939 e 81, de julho de 1944, onde foram identificados textos e imagens que referenciam diretamente o corpo masculino negro ${ }^{\mathrm{d}}$. As fontes foram analisadas a partir do referencial teóricometodológico da História Cultural ${ }^{11-13}$ que concebe os documentos como representaçóes abertas a atribuição de sentidos. Entendidas como mecanismos de significação que produzem discursos, as fontes que sustentam os argumentos deste artigo permitem narrar versôes sobre representaçóes étnico-raciais interseccionadas pelos marcadores de gênero.

O corpo do homem negro foi analisado numa perspectiva relacional com outras representaçôes de corpo presentes naquele periódico, em especial dos brancos, cuja ênfase ao longo do recorte temporal foi notadamente maior. Ao dialogarmos com as fontes a partir do conceito de representação ${ }^{14}$, tornou-se as imagens como um complexo mecanismo de significação que produz discursos, por guardar visôes de mundo e
Nação, representações de beleza também passaram a atrair a atenção das elites políticas e intelectuais ${ }^{8-10}$, dentre as quais se destacam o projeto de educação visibilizado pela Revista Educação Physica e seus colaboradores.

Enquanto diretor técnico, Hollanda Loyola teria manifestado seus ideais de regeneração racial do povo brasileiro, cujas influências fascistas foram herdadas de seus vínculos com a AIB. Em meio às páginas de uma revista que se dedicava a "vulgarizar os preceitos da Educação Física”, haveria um ideal que pretendia legar às futuras gerações força, robustez e beleza, como atributos de um corpo intelectual, moral e fisicamente perfeito.

Considerando a complexidade da questão racial entre as décadas de 1930 e 1940 e os distintos modos como eram concebidas as manifestações étnicas e as heranças biológicas das populações não brancas, este texto analisa a ausência do corpo negro nas representações de beleza masculina construídas pela revista Educação Physica no período em que Hollanda Loyola foi seu editor técnico (1939 - 1944).

desejos políticos específicos. A representação tem o potencial de orientar práticas sociais e de constituir "realidades" e identidades sociais, que não existindo em si mesmas, só adquirem sentidos mediante as formas como os significados são produzidos $\mathrm{e}$ intercambiados pelos membros de uma cultura. Sendo na e pela representação que os sujeitos e grupos se constituem, tem-se que a identidade e a diferença não existem fora dos sistemas de representação que lhe conferem significados socioculturais. Por essa razão, a representação está diretamente ligada a relaçóes de poder, em outras palavras, os grupos que dispóem dos processos de representação, controlam, definem e marcam as identidades étnico-raciais, de gênero e nacionais desejáveis e "normais". Portanto, analisar a Revista Educação Physica sobre esta perspectiva; como um artefato cultural de representação e significação, tornou o periódico uma superfície fecunda de produção de sentidos, sempre sujeita a (re) interpretaçóes, caso contrário, ocultaria as relaçóes de poder imbricadas na construção de identidades e na produçáo do mundo social expressos no e pelos textos e imagens publicados/as na revista ${ }^{15}$. 


\section{Resultados e discussão}

\section{Sadios e fortes; belos e brancos: entre a capacidade para o trabalho e o desejo de homogeneização étnico-racial}

Com a implantação do regime estado-novista, o Brasil passou a investir na industrialização como sustentáculo para o processo de modernização da Nação. Para efetivação desse projeto político, estratégias ideológicas foram criadas com o intuito de ressignificar a compreensão social do trabalho, que passaria a ser visto como um exercício capaz de conferir moral e dignidade aos homens ${ }^{\mathrm{e}}$. Sendo assim, trabalhar havia se tornado sinônimo de civilidade, progresso e um dever dos cidadáos para o desenvolvimento do país.

Constituída pela crença no dever cívico e pela robustez da população, a força de trabalho seria incentivada no Governo Vargas por mecanismos que visavam à melhoria das condiçôes ambientais que conduziriam a população a hábitos higiênicos. Como resposta a essas demandas cívicas à Educaçáo Física, foi atribuído o papel de revigorar o trabalhador e melhorar sua capacidade produtiva. Por essa razão, o pensamento intervencionista da época advogava em prol da prática periódica e racional da Educaçáo Física como elemento capaz de promover a saúde e formar um homem robusto, produtivo e íntegro ${ }^{6,14}$.

O "aperfeiçoamento da raça brasileira", o "legado de força, robustez e beleza às futuras geraçōes", assim como a "defesa do trabalho como dever cívico", foram algumas das intençốes expressas pela revista Educação Physica entre os anos de 1939 a 1944. Segundo Hollanda, a moderna Educação Física brasileira deveria ser racional e científica, cuja finalidade seria:

[...] preparar o individuo para vida, dotá-lo de predicados que o capacite a enfrentar com superioridade todas as contingencias do meio, fazê-lo forte e são e útil, desenvolvendo e aperfeiçoando as suas qualidades físicas e consequentemente as suas qualidades moraes, dentro de um programa que consulte as realidades do momento, que atenda às exigências da época $[\ldots]^{15}$.

Assim, a revista reiterava noçôes de patriotismo, moralidade, revigoramento físico e aperfeiçoamento estético da nação por meio de práticas de exercitação física. Loyola advogava em suas publicaçôes a tese de que a educação para ser completa deveria ser integral: moral, intelectual e física, sendo o ensino incompleto ao desconsiderar quaisquer desses elementos que compóem "um todo indivisível que é o homem" ${ }^{16}$. Loyola narra a educaçáo moral como uma ferramenta capaz de moldar a personalidade dos brasileiros, de identificá-los com a família e com a Pátria, incitando os sentimentos de unidade, disciplina e amor ao trabalho - a formação intelectual tinha como finalidade a construção de trabalhadores úteis, produtivos e eficientes para o bem coletivo, para o progresso da Nação e ainda, para o êxito individual dos sujeitos ${ }^{17,18}$.

De acordo com os desejos políticos pautados pelo regime estado-novista, assim como dos postulados da extinta AIB, a Revista Educação Physica constituiu-se como um artefato cultural útil às pretensôes políticas de ressignificaçáo do trabalho. As representaçóes do periódico serviram como lócus de produçâo de homens sadios e robustos, com capacidade produtiva para o desenvolvimento econômico da Nação e, sobretudo, como instrumento de reeducaçáo de corpos destinados à forja de sujeitos cientes dos valores morais e cívicos expressos em sua afeição ao trabalho.

No artigo publicado na edição número $68 \mathrm{da}$ revista, Loyola versa sobre a entrada do Brasil na Segunda Guerra Mundial ${ }^{19}$, f, fato que atribuía à Educação Física o papel cívico de robustecer os corpos masculinos e torná-los aptos à defesa da Nação. Ainda que motivado pelos acontecimentos da Segunda Guerra e pela inserção efetiva do Brasil nos conflitos mundiais, Loyola faz algumas ressalvas em favor de uma suposta identidade nacional que prezaria pela paz e pela coesão da nação. Segundo ele:

$$
\begin{aligned}
& {[\ldots] \text { sempre fomos um povo de tradiçóes pacíficas [...] }} \\
& \text { a educação de nossa juventude foi sempre dirigida no } \\
& \text { sentido da mais pura fraternidade humana }[. . .] \text { e jamais } \\
& \text { apresentou a menor restrição a qualquer estrangeiro que } \\
& \text { quisesse viver em comunhão conosco }[\ldots]^{20} \text {. }
\end{aligned}
$$

Ex-membro da Ação Integralista Brasileira, Hollanda Loyola guarda, em seus textos, vestígios dos contornos ideológicos do movimento que refutava, sobretudo aqueles que pudessem dividir a Nação, valendo-se da retórica da irmandade cristã.

Para além dos argumentos contrários aos conflitos armados, Loyola e sua política editorial defendiam a coesão nacional e a integração racial como elementos fundamentais à unidade identitária 
do povo brasileiro. Altamente articulados ao ideal de "democracia racial" "11,g, a miscigenação para os integralistas seria um processo autêntico associado às tradiçôes históricas, culturais e religiosas brasileiras desde o período colonial, sendo, portanto, um mecanismo capaz de salvar a Naçáo e recuperar a identidade nacional por meio da homogeneidade étnico-racial ${ }^{22}$.

Mesmo que os argumentos em favor da mestiçagem sejam encontrados nas proposições da AIB e nos textos publicados por Hollanda Loyola na Educação Physica, não significa que o negro, o mulato, o crioulo ou o mameluco tivessem sido colocados como tipos ideais de nacionalidade. Se por um lado a miscigenação era defendida como mecanismo capaz de contribuir com a unidade nacional, por outro, as representaçóes dos mestiços e a valorização de atributos associados ao corpo e à cultura branca indicam a defesa da mestiçagem como elemento capaz de levar ao embranquecimento da população ${ }^{22}$.

Nas páginas da Revista Educação Physica, o branqueamento via miscigenação, entretanto, não foi explicitamente propagandeado como em períodos anteriores. Nos primeiros anos do século $\mathrm{XX}$, intelectuais brasileiros, apoiados em teorias aceitas cientificamente, defendiam e divulgavam a miscigenaçáo como processo que levaria ao embranquecimento da população, uma vez que teorias racistas afirmavam que características físicas, morais e intelectuais de brancos, por serem superiores, seriam legadas às geraçóes futuras ${ }^{23-29, \mathrm{~h}}$.

De modo "sutil" e atravessado por ideais de fraternidade, solidariedade e moralidade, o racismo e a valorização do corpo branco, presentes em boa parte dos textos assinados por Loyola e, de modo geral, nas publicaçóes da revista, recebiam feiçôes de uma "ingênua" defesa dos valores cristãos de comunhão entre os povos. Os processos de mestiçagem que conduziriam ao embranquecimento teria como álibi a defesa das tradiçóes históricas do Brasil, já que a mistura étnico-racial era tida como parte constituinte da subjetividade do povo brasileiro e, por essa razão, precisava prosseguir ${ }^{22}$. Como efeito, a busca por uma identidade nacional via constituição étnica da nação invisibilizou, sob o argumento da coesão social, elementos constituintes do povo e da cultura negra nas páginas da revista. Se, para o periódico Educação Physica, a homogeneidade era sinônimo de progresso das civilizaçôes, este, por sua vez, era representado pela brancura da pele.

\section{Para a consciência do bello, o branco marmóreo das estátuas gregas e a masculinidade hígida de Antinous}

[...] nas possibilidades de cada individuo, deveria formarse uma consciência do belo. Ela [a recreação] tende, em todos os seus fundamentos, a criar um sentido do belo e uma consciência estética. Está no movimento que se executa com estilo e é um estilo de belezai.

Inserido na primeira edição da revista sob a direção técnica de Holanda Loyola, o fragmento acima compóe o artigo intitulado "A Consciência do Bello", cujo conteúdo já anunciava a intenção pedagógica de se conscientizar os leitores sobre os "verdadeiros sentidos da beleza”. Ao exibir imagens de esculturas clássicas o artigo de autoria de Maria Vernego ${ }^{30}$, "Como iniciá-los na educação estética?", publicado na edição 41, em 1940, versa sobre a importância de conduzir as crianças ao entendimento do belo como algo a ser valorizado, desejado e conquistado. A prática regular de exercícios corporais é associada a esse projeto de educação estética cujos efeitos estariam além dos atributos físicos, uma vez que a beleza advogada pela "Educação Physica” só seria plena se constituída por sentimentos cívicos, atributos morais e capacidade intelectual. Nesse sentido, caberia aos professores de Educação Física a forja de sujeitos saudáveis, robustos e belos pela exercitação diuturna de seus corpos. Segundo Loyola:

\footnotetext{
-Teu magistério é um ideal! - é preciso que compreendas a magnitude desse conceito e te situes na sociedade de acordo com o seu alcance. Cabe-te essa extraordinária tarefa social e humana - todos os cuidados para a formação do homem integral - sadio, belo e forte pela perfeição física $[\ldots]^{31}$.
}

O projeto de educação estética proposto pela Educação Physica, ao produzir representações de beleza atribuídas aos corpos masculinos, femininos e infantis, constrói um "currículo" que evidencia determinados corpos, invisibiliza outros tantos e, assim, normatiza representaçóes de gênero, sexualidades e hierarquiza as identidades étnico/raciais ${ }^{32}$. Como estratégia pedagógica que intencionava a "isenção" e a "neutralidade", imagens Gregas são constantemente utilizadas como representações "pacíficas e consensuais" de beleza, cujos sentidos de "perfeição integral" deveriam constituir o corpo social brasileiro.

Pátria representada como local onde teria florescido uma raça extraordinária; perfeita pelos 
contornos estéticos, higiênicos e pelo trato que dedicava aos corpos de seus cidadãos $^{33}$, a Grécia Antiga, de diversos modos, encontra-se presente em todos os números da revista. Considerada o berço da poesia, das artes e da filosofia, a civilização grega teria alcançado o máximo da limpeza, robustez, saúde e beleza, por vias de uma educação moral e física. Os esforços empreendidos para o aperfeiçoamento humano teriam conquistado a pureza da raça que, além dos aspectos físicos, alcançava os valores morais e os atributos intelectuais. Os "monumentos" 34 gregos reverenciados pela "Educação Physica" indicam uma civilização cujo percurso em direção à perfeição deveria ser glorificado e imortalizado nos desejos patrióticos de países como o Brasil.

Entre saberes técnicos e argumentos científicos, as "verdades" sobre a perfeição grega são reafirmadas por meio de imagens de corpos masculinos como os de Antinous, Apolo e Doríforo. Ao fazer uso de particularidades associadas à Grécia Antiga, a revista Educação Physica confere valor, neutralidade e inquestionabilidade a seus argumentos por meio de uma fusáo de elementos positivados de um passado distante com as memórias e os desejos ideológicos de seu tempo ${ }^{35}$.

Publicados de modos esparsos e aparentemente despretensiosos, ao mesmo tempo em que reiteram a "virtude" secularmente presente na memória coletiva, fragmentos da antiguidade grega são apropriados politicamente pela Educaçáo Physica como argumentos que legitimam seu projeto estético, científico e moral.

Ao representar a beleza a partir das ideias de perfeição associadas à arte e à arquitetura clássica, o projeto da revista, que propóe educar para a "consciência do belo”, faz uso de concepçóes simplificadas, românticas e tornadas consensuais ao longo do tempo para, então, agregar novos elementos e invisibilizar outros tantos. Portanto, as apropriaçóes e os usos de imagens e textos alusivos à Grécia operam um reconhecimento entre imagem/texto e observador/leitor capaz de acomodar distintos ideais e distintos tempos históricos. Numa proposta permeada por saberes técnico/científicos do século XX, os usos da antiguidade clássica levam ao convencimento acerca de verdades sobre "o belo", "o civismo" e a conduta moral desejável para homens e mulheres ${ }^{35}$.

Há tempos sendo reconstruída com o auxílio de suas ruínas e obras de arte, a antiguidade grega tem auxiliado a projetar desejos políticos em diferentes lugares do mundo ocidental ${ }^{36, j}$. Incorporadas aos desejos e anseios da revista Educação Physica, as referências gregas prestam-se a um programa cientifico, moral e cívico que ajuda a sedimentar as populares noçóes acerca da antiguidade clássica, vinculadas aos ideais de beleza que deveriam reger o povo brasileiro ${ }^{\mathrm{k}}$.

Geograficamente localizada na Europa, a Grécia e sua estética clássica falam do lócus primordial da modernidade. Civilidade, vanguarda e cultura são alguns dos atributos comumente associados pela Educação Physica ao continente europeu, cujos ideais deveriam inspirar o projeto de nação para o Brasil. Nas páginas da revista, o eurocentrismo ${ }^{37}$ manifestado em corpos brancos e em imagens gregas evidencia valores e normas provenientes de um desenvolvimento ocidental que historicamente se anuncia como universalizante e moderno ${ }^{38}$.

Os modelos Gregos, representantes máximos de beleza e perfeição, atestam concepçôes eurocêntricas constitutivas do projeto editorial da Educação Physica, que, apoiadas em princípios de progresso e civilização, geram, como efeito, a beleza branca de matriz europeia como possibilidade única.

Representado como o mais perfeito dos modelos gregos, Antinous parece ter sido eleito o emblema de corpo e masculinidade almejados pela Educação Physica. A beleza, a robustez e a moral de Antinous são constantemente atestadas a cada menção a seu nome, sugerindo que seu grau de pureza tornaria dispensável quaisquer problematizaçóes sobre sua memória. Num esforço de construção de uma metáfora de perfeição, sua presença é constante, mas as referências à sua trajetória são mínimas.

Nascido em Bitinia, uma região da Antiga Grécia, por volta de 110 d.C. ${ }^{39,40,1}$, Antinous teria sido eleito o favorito do imperador Adriano, condição que o permitia desfrutar das prerrogativas de viver como seu efebo e amante, ainda que em um período cuja prática da pederastia entrava em declínio, em decorrência da ascensão do cristianismo em Roma. Descrito por Adriano, como emblema de beleza masculina, Antinous era destacado como jovem, viril, gracioso e melancólico.

Sua morte por afogamento teria sido provocada em uma das viagens da Corte do Imperador pelo rio Nilo, em 130 d.C. A partir de então, o sofrimento de Adriano mobilizá-lo-ia a perpetuar a memória de Antinous, edificando uma cidade em sua homenagem, cunhando moedas com seu rosto e convocando jogos e festas em seu tributo. Templos foram construídos, e seu nome passou a ser cultuado, recebendo honras tais quais as de divindades como Apolo, Hermes, Dionísio, Osíris e Mercúrio ${ }^{41}$.

$\mathrm{O}$ culto à sua divindade teria sucumbido alguns 
séculos depois, mediante as forças do cristianismo, que, por volta de 350 d.C., já havia reescrito sua história a partir dos determinismos cristáos. Ao evidenciar algumas características e suprimir outras tantas, o cristianismo reinventa a história de Antinous, que passa a ser evidenciado como vítima e escravo do Imperador Adriano, cujos desejos desregrados teriam o conduzido ao trágico falecimento.

A aura de mistério que rondou esse personagem interessou autores como Oscar Wilde, Schiller, Goethe, Stefan George e, já no século XX, Fernando Pessoa ${ }^{\mathrm{m}}$, Marguerite Yourcenar, Fernando de Azevedo, Renato Kehl e Hollanda Loyola. Ao longo dos anos e por vias de diversos autores, a trajetória de Antinous teve seus traços moralizados a fim de adequar-se às diversas expectativas políticas e religiosas ${ }^{40}$.

Ao longo dos textos da revista Educação Physica, as informaçóes sobre Antinous são pouco profundas e escassas, versando sobre suas referências de beleza e moralidade. Completamente desinteressada sobre as possíveis trajetórias do jovem grego, o uso das imagens do mito, pela Educação Physica, sinalizam um projeto de corpo-nação, inspirado em princípios higiênicos, racistas e heteronormativos.

Ainda que o modelo de masculinidade advenha de um personagem sobre o qual pouco teria se falado, questionamentos sobre sua misteriosa e indeterminável memória seriam improváveis, afinal, Antinous estaria sendo construído como "Padrão da Educação Integral: física, moral e intelectual"n. Expostos a cada ediçáo da revista, os marcadores anatômicos determinantes de seu sexo seriam suficientes para atestar sobre a "legitimidade" e "normalidade" de seus desejos e prazeres, afastando qualquer instabilidade sobre a autenticidade de sua condição heterossexual. De modo compulsório, a heterossexualidade de Antinous é construída mediante paradigmas universalizantes, por aqueles que entendem haver, na natureza, determinantes entre sexo, gênero e sexualidade, retórica revestida de cientificidade bastante utilizada pela revista Educação Physica ${ }^{42}$, . Portanto, para que Antinous passe de efebo adepto da pederastia à emblema de perfeição moral intelectual e física, bastaria o silêncio sobre sua subversiva e ambígua sexualidade.

Por mais que o silêncio e a indeterminação fossem predicados incompatíveis com a pretensa racionalidade científica propagandeada pela Educação Physica, o personagem grego tornou-se elemento fundamental no processo de construção de um modelo de masculinidade estável e universal. $\mathrm{O}$ minimalismo das informaçóes sobre Antinous e sua associação às virtudes gregas permitiram à Educação Physica construir, de modo consistente, os ideais de virilidade, moralidade e beleza. Neste caso, o não dito reiteraria a verdade que se pretendia disseminar e sedimentar. O local de destaque atribuído a Antinous, presente no centro da página de cada novo editorial da revista, edificava, fazendo uso do glamour da cultura helênica, aquilo que era singular e padrão em detrimento das múltiplas possibilidades de corpos masculinos.

Desse modo, o mito grego é presentificado em imagens colaborando para a construção de uma representação de beleza masculina, que sedimenta prerrogativas raciais de sujeitos brancos e heterossexuais e reforça, juntamente com as atividades físicas, atributos morais almejados naquele momento: saúde, robustez, espírito patriótico e disposição para o trabalho.

\section{O corpo não dito e não visto, "para maior glória do Brasil"}

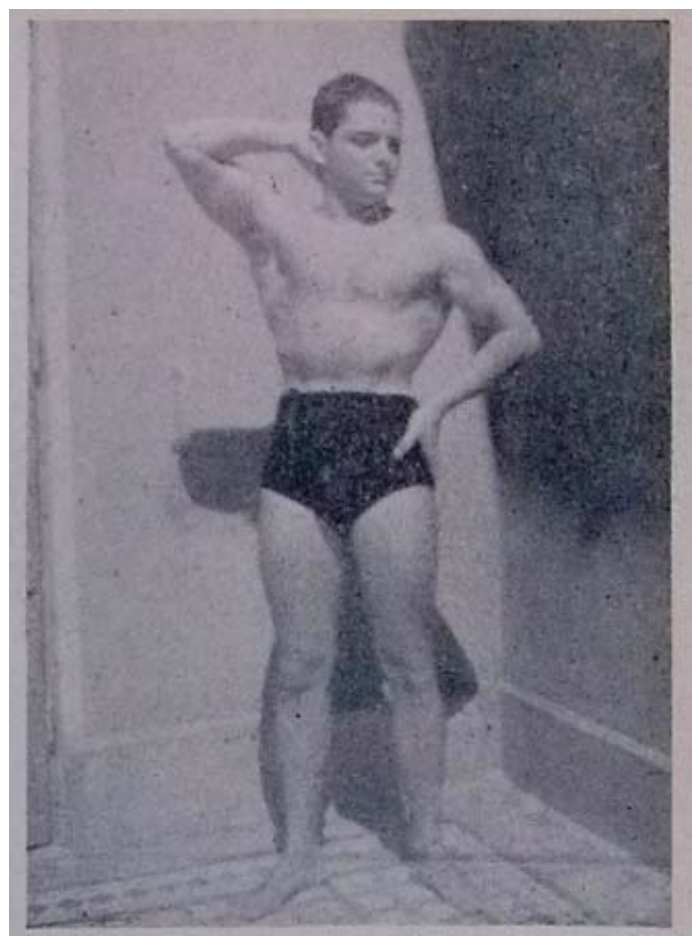

FIGURA 1 - "Mais um belo Modelo [...]”.

Fonte: Revista Educação Physica, 1941, n 59, p. $11 .{ }^{43}$

José Antônio Fernandes é um jovem estudante e provável atleta. Na página 11 do número 59 da revista Educação Physica, sua foto é publicada junto ao seguinte texto: "Mais um belo modelo da nova geração que a educação física está construindo no Brasil”. 
Disciplinado, saudável e robusto, nascido na Bahia, José Antônio Fernandes ajuda a marcar, com a brancura de sua pele, representaçóes de beleza para a revista Educação Physica. Ainda que proveniente do estado brasileiro que, naquele momento, possuía o maior número de negros do país ${ }^{44}$ o "verdadeiro sentido da beleza" teria eleito seu corpo branco dentre as inúmeras outras possibilidades.

$\mathrm{Na}$ edição número 38 , a imagem do ginasta culturista francês E. Bonnet é exibida como modelo de perfeição física, cujo corpo teria sido construído pela prática racional e constante de Educaçáo Física ${ }^{45, p}$. Vestido em traje de banho, seus músculos são exibidos sob a pele bronzeada, efeito da salutar exposição ao sol durante a exercitação ao ar livre.

Sem camisa, com os braços para trás e com o olhar distante, o corpo do atleta José Roberto Soares é glorificado como mais um representante da Educação Integral proporcionada pela racionalidade dos exercícios esportivos. Belo, jovem e branco, a foto do atleta sugere a materialização em carne e ossos da perfeiçâo manifestada nas estátuas gregas. Segundo a revista:

Uma nova geração está se formando no Brasil pela educação física, definindo-se um tipo racial sadio, forte e belo. O jovem atleta José Roberto de Macedo Soares [...] é um magnífico modelo dessa nova geração. Apreciemse-lhes a harmonia das linhas e a perfeição das formas - é o resultado vitorioso de sua dedicação ao exercício físico. Todos os jovens patrícios teem a obrigação de imitá-lo para a maior glória do Brasil ${ }^{46, q}$.

Além dos aspectos puramente estéticos, argumentos científicos também foram utilizados pela revista como legitimadores de modelos de beleza. No artigo, Um pouco de Endocrinologia ${ }^{47}$, associada aos discursos que pretendiam disseminar princípios de saúde, estava a produção de um determinado senso estéticor. Segundo o texto, a desarmonia da constituição dos dentes, da pele, do cabelo, dos olhos, das mãos, dos pés e da estatura, estaria relacionada à função deficiente ou excessiva das glândulas endócrinas. Como antítese ao desalinho corporal, dois homens brancos e seminus são colocados como referência de saúde.

$\mathrm{O}$ uso de imagens associadas a textos foi um recurso muito explorado pela revista, como forma de demonstrar com precisão o que se pretendia comunicar. Muito mais do que mera ilustração, as imagens manifestam os desejos políticos de um periódico, ao mesmo tempo em que evidenciam representações mais amplas, porém não uníssonas, sobre beleza e raça.

$\mathrm{O}$ não visto e o não dito nas páginas da revista pode ser entendido como indesejável ou marginal. Mesmo sendo inegável a presença de outros grupos étnicos vivendo no Brasil, a Educação Physica parece nortear suas publicações que envolvem o belo e o desejável dentro do que considerava adequado, legítimo e normal para a nação da época, ou seja, corpos brancos. Apesar de não haver mençôes textuais que narrem o corpo negro como não belo, sua ausência nas representaçôes de beleza distancia esse corpo do entendimento de beleza masculina. Branco, jovem, trabalhador e disciplinado, a masculinidade representada como central na Educação Physica constrói, como efeito, a marginalidade de outras possibilidades de corpo. Localizado fora do centro ${ }^{48}$, os corpos marginais seriam todos aqueles não representados como belos, tais quais os negros, índios, deficientes, os não heterossexuais. Ao tornar a beleza negra impublicável em suas páginas, a revista Educaçáo Physica articula-se ao efervescente e polissêmico debate racial colocado nos anos de $1930 \mathrm{e}$ 1940, cujo contexto marca a pretensão de compor uma identidade étnica como mecanismo político, que tinha por finalidade a unidade nacional.

Com o decréscimo das correntes imigratórias europeias, tornou-se emergencial controlar a entrada de imigrantes não brancos via implementação de $\operatorname{cotas}^{49,50}$, , cuja finalidade seria selecionar sujeitos capazes de contribuir para o desenvolvimento econômico e a formação étnico-racial do país. Num contexto em que raça era uma questáo de segurança nacional, determinados corpos deveriam ser evidenciados ao passo que outros deveriam ser invisibilizados.

Sob o argumento de degeneração social, moral e física, o corpo negro ${ }^{t}$ foi constituído por parte da elite da época" como elemento pernicioso à campanha de nacionalização do Governo Vargas. Apesar de presente na década de 1930, a associação da raça negra à inferioridade não era uma prática consensual entre a elite política e intelectual. Naquele momento algumas autoridades dedicavam-se à valorização das matrizes culturais negras ${ }^{\mathrm{v}}$, casos de Arthur Ramos ${ }^{51,52, \mathrm{w}}$, Gilberto Freyre $^{53, x}$ e Edgard Roquette Pinto ${ }^{54-55, y}$.

Autor da obra Casagrande e Senzala, cuja primeira edição data de 1933, Gilberto Freyre faz uma leitura do quadro agrário escravagista dos séculos XVI e XVII no nordeste brasileiro. Ao sinalizar o processo de miscigenação entre brancos, negros e índios, Freyre argumenta em favor de um hibridismo cultural que emerge em paralelo à mistura das raças. Ao positivar as heranças culturais advindas dos índios, negros $\mathrm{e}$ europeus, Freyre responde às questôes de identidade 
nacional, deslocando a ênfase da biologia para a cultura, constituindo sólido argumento contrário aos biodeterminismos. A ideia de democracia racial teria se constituído a partir da miscigenação de aspectos culturais e raciais, dando origem à crença de um povo democrático, sem preconceitos, dado o rompimento de fronteiras entre aspectos biológicos e culturais específicos de cada raça ${ }^{56}$.

Ainda que o olhar positivo sobre negros, índios e mestiços no Brasil aponte para um momento mais acolhedor às diferenças étnicas e raciais, a tese central de Freyre evidencia o embranquecimento como "consequência natural" do processo de miscigenação ${ }^{25}$. Por mais que as características físicas e culturais brancas sejam indicadas como hierarquicamente superiores às demais raças, Casagrande e Senzala sinaliza uma reelaboraçáo do racismo que passa a ser menos explícito, diferente do racismo declarado idos século XIX e anos iniciais do século XX ${ }^{57}$. Nesse sentido, na década de 1930, tornam-se cada vez mais evidentes posicionamentos como os de Arthur Ramos, Gilberto Freyre e Roquette-Pinto, que, coletivamente, produziram manifestos contrários ao preconceito racial, base para um movimento antirracista no Brasi ${ }^{51}$.

A década de 1930 ainda presencia o protagonismo negro que alcança visibilidade às suas associaçôes e produçôes culturais $^{58, z}$. De modo autônomo, grupos identitários são organizados como movimento de resistência a políticas brasileiras que não contemplassem, em seus programas, a luta em favor das demandas sociais e culturais vinculadas às populaçóes náo brancas.

A Frente Negra Brasileira foi a mais expressiva entidade negra do país das primeiras décadas do século $\mathrm{XX}^{58,59, \text { aa }}$. Com o lema "Congregar, Educar e Orientar", a Frente Negra pretendia aglutinar as diversas organizaçóes associativas a fim de constituir um movimento negro denso e global. $\mathrm{O}$ movimento que chegou a abarcar cerca de 20 mil pessoas organizou departamentos artísticos, esportivos, jurídicos, médicos, pedagógicos e de imprensa, este último com a publicação de um jornal próprio denominado "A Voz da Raça" ${ }^{\circ 0}$.

A organização negra fez emergir ainda $o$ jornal "A Raçă", em 1935, em Uberlândia (MG) e o jornal Alvorada, de Pelotas (RS), periódico da imprensa negra de maior longevidade do país, $1907-1965^{\text {bb }}$. Tais jornais denunciavam as distintas mazelas, além de serem tomados como lócus de discussão sobre as formas de enfrentamento ao racismo na sociedade brasileira do início do século XX, servindo de veículo para evidenciar um regime de segregaçáo racial que ocorria em diversas cidades do país. Com o intuito de congregar as comunidades e sujeitos negros, assim como constituir um senso de solidariedade e resistência contra as representaçóes negativas associadas aos negros e sua cultura ${ }^{58}$, a imprensa negra constituiu um sistema de representaçáo positivado sobre sua ancestralidade e modos de organização culturais, dando ênfase a representaçóes de beleza, impensadas para revistas como a Educação Physica.

Entre favoráveis e contrários às manifestações étnicas e às heranças biológicas da população negra, havia a necessidade de se construir representaçōes acerca de um novo homem para o Brasil. Ainda que movimentos em prol de uma "democracia racial" estivessem se edificando naquele momento, suas açōes não foram capazes de problematizar representaçóes de corpo como as propagandeadas pela revista Educação Physica, afinal, o processo de mestiçagem perpassaria, naturalmente, pela assimilação dos traços culturais e físicos da população branca.

A retórica moralista, ética e cristâ, que distanciava a AIB de discursos assumidamente racistas, teria sido acolhida e materializada no processo de editoração técnica de Hollanda Loyola. Ao evidenciar corpos brancos e invisibilizar/silenciar qualquer possibilidade de representaçáo de beleza negra, Loyolla e a revista Educação Physica teriam encontrado a fórmula do não enfrentamento que perpassa a propagaçáo de um senso de integraçáo racial ${ }^{22}$. Assim, sob a intençáo de se construir a imagem de um país homogêneo, fez-se necessário tornar menos evidente a diversidade política, cultural e étnico-racial como forma de construir uma identidade nacional ${ }^{49}$.

Na medida em que a Revista Educação Physica investiu em uma dada representação de beleza masculina, invisibilizando outras, corpos são forjados na estreita relaçáo com uma moral religiosa e liberal, cuja finalidade seria uma representaçâo de homens brancos, trabalhadores, fortes, pais de família, capazes de gerar o futuro próspero para o Brasil, seja via sua força de trabalho ou pela formação de uma prole sã.

O corpo masculino representado em revistas especializadas, como a Educaçáo Physica, parece ser um interessante indicador das concepçôes de masculinidade que se manifestavam em debates científicos ao longo das décadas de 1930 e início dos anos 1940. Tomado como inscrição e registro de distintos projetos políticos, o corpo da população recebeu atenção de parte da elite política e intelectual dos idos 1930-1940 e expressou pretensóes nacionalistas e de composição de uma identidade étnico-racial, anseios que teriam sido acolhidos pela revista Educaçáo Physica, no período de 1939 a 1944. 
Ao longo da direção técnica de Hollanda Loyola, o debate produzido pela revista teria produzido representaçóes reguladoras do corpo masculino, pautadas em concepçóes morais e legitimadas por argumentos científicos.

Com a intenção de ressignificar as atividades laborais como sinônimo de moralidade e civismo, elementos fundamentais ao progresso e engrandecimento da Nação, características de disciplina e predisposiçáo ao trabalho são associadas ao corpo masculino. Inseridos em um período marcado pelo desejo manifestado pelo Governo Vargas e da Ação Integralista Brasileira de coesão nacional e constituição identitária, Holanda Loyolla e a Educação Physica advogam em favor da mistura étnico-racial, cujo processo "naturalmente" levaria ao pacífico embranquecimento da população.

Assim, a revista constrói um padrão de beleza masculino intimamente ligado à juventude, disciplina e hombridade, recorrendo, para tanto, às imagens de estátuas gregas ou às fotografias de jovens atletas em poucos trajes, o que auxiliou a produzir um modelo eurocêntrico de corpo, cujos atributos de beleza foram relacionados à perfeiçáo moral e intelectual, além de física.

À margem do projeto de educação do senso estético proposto pela revista, os corpos negros foram invisibilizados quando imagens e textos dimensionavam aspectos positivos como beleza, moralidade e inteligência. Ainda que na década de 1930, organizaçóes negras e grupos de intelectuais defendiam abertamente representaçóes positivas acerca da cultura e raça negra, tais movimentos náo teriam encontrado ressonância nas páginas da Educação Physica. Sem negar a existência das comunidades negras e sem sinalizar textualmente sobre a possível "fealdade" proveniente dos corpos negros, a revista opta pelo silêncio como modo de não enfrentamento e busca por coesão/integralização das raças. Desse modo, ao invisibilizar possíveis representaçôes de beleza negra e ao reiterar os códigos dominantes a cada edição, a revista produz, como efeito deste jogo de representaçôes, um processo que coloca à margem os homens de cor e todos aqueles que se distanciam do centro.

Nas décadas de 1930 e 1940, a Educação Physica advogava, nos circuitos culturais, a necessidade de avigorar o corpo masculino e torná-lo belo e robusto. Em meio à produçấo de sentidos das representaçóes de beleza masculina, a ausência de corpos negros representados nos discursos de beleza defendidos e vulgarizados pelo periódico produziu uma pedagogia do senso estético que evidencia a beleza masculina como elemento próprio dos corpos brancos.

\section{Notas}

a. A Revista Educação Physica foi editada no Rio de Janeiro pela Companhia Brasil Editora, entre 1932 a 1945. Emergiu da iniciativa dos professores de Educação Física Paulo Lotufo, Oswaldo Murgel Rezende, Roland de Souza e Francisco de Assis Hollanda Loyola ${ }^{3}$.

b. Criada por Plínio Salgado em 07 de Outubro de 1932, a AIB, de inspiração fascista, adotava um modelo de organização que seguia um conjunto doutrinário de rituais e normas, dentre os quais, a obrigatoriedade de vestirem-se com camisas verdes e gravatas pretas, saudarem-se com o braço direito estendido, bradando a palavra de origem tupi-guarani "anauê" e usarem como símbolo a letra do alfabeto grego sigma $(\Sigma)^{2,4}$.

c. Também denominado "Era Vargas”, foi o período em que Getúlio Vargas governou ininterruptamente por 15 anos. Considerado o marco de ruptura da República Velha, a "revolução de 1930" que colocou Vargas no poder foi apoiada por forças do exército que colocaram em discussão a idoneidade do processo eleitoral. De modo geral a Era Vargas é dividida em três fases: 1) Governo Provisório 1930 a 1934; 2) Governo Constitucional, 1934 a 1937; 3) Estado Novo, 1937 a $1945^{8}$.

d. A coleção completa da Revista Educação Physica encontra-se disponível para acesso no acervo histórico da biblioteca Edgard Esperb da Escola de Educaçáo Física, Fisioterapia e Dança da Universidade Federal do Rio Grande do Sul. Números da mesma revista também estão disponíveis no CEMEF (Centro de Memórias da Educação Física) da Universidade Federal de Minas Gerais.

e. O Brasil foi um país onde o trabalho escravo se estabeleceu durante quatro séculos, dessa forma, articular o ato de trabalhar com cidadania, riqueza, moralidade e dignidade, enquanto construção de uma identidade política e social para o trabalhador não foi um movimento simples ${ }^{13}$.

f. Em Agosto de 1942, seis embarcaçóes comerciais brasileiras foram afundadas no litoral baiano e sergipano em pouco menos de uma semana. Como sequência desses ataques, o Brasil declarou guerra, em aliança aos Estados Unidos, à Alemanha 
e à Itália naquele mesmo mês. O Brasil esteve presente na Segunda Guerra Mundial entre os anos de 1942 e $1945^{20}$.

g. A democracia racial foi uma ideologia vulgarizada pelos intelectuais do país que pregava a existência de uma relaçáo harmoniosa entre negros e brancos no Brasil, desse modo, ocultava as tensôes e a desigualdade existente entre raças e desarticulava a edificação de uma política antirracista sob o argumento de que não se combatia o que não existia, ou seja, os conflitos raciais ${ }^{21}$.

h. A produção de teorias como esta se deu como alternativa a teorias (climáticas e racistas) aceitas no círculo intelectual que, no final do século XIX, condenavam o Brasil e sua população. Cabe ressaltar que esse foi um movimento complexo que comportava grandes contradiçóes, neste sentido, para uma melhor compreensão, indica-se: Pimenta Rocha ${ }^{23}$, Nancy Leys Stepan ${ }^{24}$, Thomas Skidmore ${ }^{25,26}$, Lilia Moritz Schwarcz ${ }^{27}$, Célia Marinho de Azeredo ${ }^{28}$, Roberto Ventura ${ }^{29}$. i. A Consciência do bello, Revista Educação Physica, Rio de Janeiro, n. 34, p. 32.1939.

j. Em outros momentos e por outros autores a antiguidade clássica também auxiliou a legitimar argumentos como os do médico Eugenista Renato Ferraz Kehl, do Biotipologista Valdemar Berardinelli e do importante intelectual brasileiro, Fernando de Azevedo ${ }^{5,36}$.

k. Almeida, A Liturgia... op. cit., In: Soares, Corpo e ... op. cit., p. $180^{35}$.

1. Os dados sobre o nascimento de Antínoo são imprecisos, pois era um jovem completamente desconhecido até sua ascensão como favorito do imperador Adriano, presumivelmente por volta de 123 d.C $\mathrm{C}^{39,40}$.

m. Aqui é interessante ressaltar que Fernando Pessoa escreve o poema Antínoo em 1915, sendo publicado em Lisboa em 1918, praticamente no mesmo período que Fernando de Azevedo escreve Antinoüs: estudo de cultura athletica. Para o poeta português, Antínoo era o poema mais obsceno que havia escrito ${ }^{40}$.

n. Em praticamente todas as publicaçóes assinadas por Hollanda Loyola, a imagem de Antínoo estampa o centro da página como representante máximo da educação integral.

o. Ao investigar as imagens das mulheres na Revista Educação Physica, Goellner ${ }^{42}$ sinaliza que representaçóes de beleza, maternidade e feminilidade teriam sido fundamentadas pelo periódico a partir de uma "essência" feminina que seria emanada da biologia de seus corpos. A revista Educação Physica teria ainda advogado em favor dos fundamentos biotipológicos que diziam haver, no corpo, indicadores capazes de predizer sobre aptidóes físicas e intelectuais 5 .

p. Revista Educação Physica, Fotografia, 1940, p. $8^{46}$.

q. Revista Educação Physica, Fotografia, 1941, p. $11^{47}$.

r. Revista Educação Physica, Um pouco de endocrinologia, Rio de Janeiro, n. 40, p. 40-42 e 66, 1940.

s. Medidas restritivas expressas no Art. 121 da Constituição de 1934 e mantidas na Constituição de $1937^{49,50}$.

t. Vale assinalar que outros tantos grupos étnicos e políticos se tornaram "indesejáveis" naquele momento em nome da política nacionalista, dentre os quais, judeus, ciganos, japoneses, socialistas e comunistas, sobretudo, a partir do regime estado-novista. Em termos de cor, negros/as e amarelos/as foram convertidos em elementos perturbadores ao processo de formação nacional $(1937-1945)^{50}$.

u. Dentre os quais, alguns membros influentes da sociedade brasileira da época, caso de Artur Hehl Veiga, componente do Conselho de Imigração e Colonização do Estado Novo (1937 - 1945). Suas ideias pleiteavam a imigração branca "latina" e a restriçáo da entrada de imigrantes negros/as e amarelos/as no Brasil. Neiva também desempenhou o cargo de deputado na Assembleia Nacional Constituinte entre 1933 e 1934, momento em que apresentou uma emenda política, eugênica e racista que sugeria apenas o ingresso de imigrantes brancos/as em território nacional ${ }^{49,50}$.

v. Apesar de haver a intenção de alguns intelectuais se posicionarem contrários a algumas manifestaçóes de racismo e valorizarem traços culturais de outras etnias que não a branca, a produção de boa parte desses sujeitos sinaliza, por vezes, alguns traços de racismo e de um processo de hierarquização entre as culturas. A busca por um "antirracismo homogêneo" em suas obras incorre em alguns riscos.

w Médico, catedrático da Faculdade Nacional de Filosofia, da Universidade do Brasil, Arthur Ramos foi ainda presidente da Sociedade Brasileira de Antropologia e Etnografia. O percurso político-acadêmico de Arthur Ramos perpassa pelos movimentos afirmativos da população negra e mestiça, pela negação a doutrinas raciais de caráter pessimista ${ }^{5,51,52}$.

x. Partidário das ideias de Roquette-Pinto, Fróes da Fonseca e Franz Boas, o sociólogo Gilberto Freyre constrói Casa Grande e Senzala, obra que, ao longo da década de 1930, reuniria grande parte da intelectualidade nacional em favor de uma perspectiva racial distinta do radicalismo eugênico ${ }^{53}$

y. Médico-antropólogo, Roquette Pinto foi diretor do Museu Nacional de Antropologia do Rio de Janeiro entre 1916 e 193654. Em 1929, em ocasião do I Congresso Brasileiro de Eugenia, pronuncia-se, por meio da conferência: "Nota sobre os typos anthropológicos do Brasil”, em defesa do mestiço, proferindo duras críticas aos eugenistas que, partindo dos bioderminismos, colocavam o negro, o índio e o mestiço na condição de degenerados e, portanto, perniciosos à 
nação. O texto de autoria do pesquisador do Museu Nacional tornou-se importante referência para a constituição da obra "Casagrande e Senzala", de autoria de Gilberto Freyre ${ }^{53,55}$

z. Dentre as organizaçóes negras datadas da década de 1930 e 1940, destacam-se: "Movimento Brasileiro contra o Preconceito Racial" (1935); "Associação dos Brasileiros de Cor" (1938) e a União Nacional dos Homens de Cor ${ }^{58}$.

aa. Assim como todas as outras organizaçóes político-partidárias, a Frente Negra Brasileira foi fechada, passando a se chamar União Negra Brasileira e, posteriormente, Clube Recreativo Palmares. Dadas as condiçôes totalitárias do Brasil naquele momento, a Frente Negra Brasileira não teria conseguido se reestruturar desde então ${ }^{58,59}$.

bb. Pode-se ainda destacar os seguintes periódicos: "O Alfinete (1918)"; "A Liberdade (1919)"; "O Kosmos" e "O Elite" (1924), "Escravos” (1935), “O Progresso” (1931); "Promissão” (1932); “Cultura Social e Esportiva” (1934), dentre outros.

\begin{abstract}
The new generation which Physical Education is building in Brazil: sound, strong, beautiful and white

This article analyzes the absence of the black body as representation of male beauty in the magazine Educação Physica between 1939 and 1944, period in which Hollanda Loyola, renowned professor and member of the Ação Integralista Brasileira, led the journal's technical direction. The debate proposed by the magazine, more than somewhat, determined the standards and representation of the male body, guided by moral and legitimated by scientific arguments, presenting in their publications the idea of beauty as an attribute solely of white bodies. As a possibility, representations of black beauty were unheard of, electing for that, white men who were hard workers and strong, had families and were able to generate a prosperous future for Brazil, either through workforce or by producing healthy offspring. Intending to build an image of an homogeneous country, it was necessary to make the political, cultural and ethnic diversity less evident as a way of building a national identity. Thus the magazine disregarded "men of color" and all those who fell away from the centrality of white bodies.
\end{abstract}

KeYwords: Magazine Educação Physica; Hollanda Loyola; Male Beauty; Black Body.

\title{
Referências
}

1. Simôes RD, Goellner SV. Educação Física e esportes na Ação Integralista Brasileira: Hollanda Loyola e a educação do corpo. Rev Bras Educ Fís Esporte. 2012;26(2):263-272.

2. Sentinelo JT. O lugar das "raças" no projeto de nação da Ação Integralista Brasileira. Rev Espaço Acad. 2010; 9(108):145-152.

3. Schneider O, Ferreira Neto A. Estratégias editoriais, enciclopedismo, produtos e publicidade na revista Educação Physica (1932-1945). Movimento. 2004;10(3):23-52.

4. Fagundes PE. Morte e memória: a necrofilia política da Ação Integralista Brasileira (AIB). Varia História. 2012; 28(48):889-909.

5. Silva A. Nos domínios do corpo e da espécie: eugenia e biotipologia na constituição disciplinar da educação física. Porto Alegre: Orquestra, 2014.

6. Linhales MA, Lima DMD, Oliveira LT. Médicos e Educadores na "Secção de Educação Physica e Hygiene" da Associação Brasileira de Educação. XVI Conbrace e III Conice. Salvador-BA, 2009. Disponível em: http://www.rbceonline.org. br/congressos/\%20index.php/CONBRACE/XVI/paper/viewFile/489/825.

7. Simôes RD, Goellner SV. A educação do corpo para o "soldado integral", "forte de físico, culto de cérebro e grande de alma”. Motriz. 2012:327-337.

8. Pandolfi D, organizador. Repensando o Estado Novo, Rio de Janeiro: Ed. Fundação Getúlio Vargas, 1999.

9. Seyfert G. Colonização, imigração e a questão racial no Brasil. Rev USP. 2002;(53):117-149. 
10. Flores MBR. A Política da Beleza: Nacionalismo, corpo e sexualidade no projeto de padronização Brasílica. Diálogos Latino-americanos. 2000. p 88-109.

11. Pesavento SJ. História \& história cultural. Belo Horizonte: Autêntica, 2003.

12. Falcon FJ. História cultural: uma visão sobre a sociedade e a cultura. Rio de Janeiro: Campos, 2002.

13. Chartier R. Textos, impressão, leitura. In: Hunt L, organizador. A Nova História Cultural. 2. ed. Sáo Paulo: Martins Fontes, 2001.

14. Hall S. Representation: cultural representations and signifying practices, Londres, Sage:The Open University, 1997.

15. Hall S. A identidade cultural na pós-modernidade. 5. ed. Rio de Janeiro, RJ: DP\&A, 2001.

16. Gomes AC. Ideologia e trabalho no Estado Novo. In: Pandolfi D, organizador. Repensando o Estado Novo, Rio de Janeiro: Ed. Fundação Getúlio Vargas, 1999, p.53-73.

17. Góis Junior E, Lovisolo HR. A educação física e concepções higienistas sobre raça: uma reinterpretação histórica da educação física brasileira dos anos de 1930. Rev Port Ciênc Desporto. 2005;5(3):322-8.

18. Loyola H. Educação Física. Rev Educ Phys Rio de Janeiro. 1939;(35):9-65.

19. Loyola H. Instrução moral e cívica. Rev Educ Phy Rio de Janeiro. 1940;(48):9.

20. Loyola H. Educação Integral. Rev Educ Phys Rio de Janeiro. 1939;(34):9-67.

21. Loyola H. Pais e Professores. Rev Educ Phys Rio de Janeiro. 1941;(52):9.

22. Loyola H. Estamos em guerra. Rev Educ Phys, Rio de Janeiro. 1942;(68):11.

23. Alves VC. Ilusão desfeita: a "aliança especial” Brasil-Estados Unidos e o poder naval brasileiro durante e após a Segunda Guerra Mundial. Rev Bras Política Intern. 2005;48(1):151-177.

24. Domingues P. O mito da democracia racial e a mestiçagem no Brasil (1889-1930). Diálogos Latino-americanos. 2005; (10):115-130.

25. Cruz NR. O integralismo e a questâo racial: a intolerância como princípio. [tese]. Niterói: Programa de Pós-Graduação em História da Universidade Federal Fluminense, 2004.

26. Rocha P. A higienização dos costumes: Educação escolar e saúde no projeto do Instituto de Hygiene de São Paulo (1918-1925). Campinas SP: Mercado das Letras, São Paulo: Fapesp, 2003.

27. Stepan NL. A hora da eugenia: raça, gênero e nação na América Latina, Rio de Janeiro: Fiocruz, 2005.

28. Skidmore T. Preto no branco. São Paulo: Paz e Terra, 1976.

29. Skidmore T. Racial ideas and social policy in Brazil - 1870-1940. In: R. Graham, organizador. The idea of race in Latin America - 1870-1940. Austin: University of Texas Press, 1990.

30. Schwarcz LM. O Espetáculo das raças: cientistas, instituiçóes e questão racial no Brasil. São Paulo: Companhia das Letras, 2001.

31. Azeredo CM. Onda negra, medo branco. Rio de Janeiro: Editora Paz e Terra, 1987.

32. Ventura R. Estilo tropical: história cultural e polêmicas literárias no Brasil. São Paulo: Companhia das Letras, 1991.

33. Vernego MS. Como iniciá-los na educação estética. Rev Educ Phys Rio Janeiro. 1940;(41):18-20.

34. Loyola H. Profissão de fé. Rev Educ Phys Rio de Janeiro. 1943;(72):11.

35. Silva TT. O currículo como fetiche: a poética e a política do texto curricular. 2. ed. Belo Horizonte, MG: Autêntica, 2001.

36. Kehl R. A beleza feminina: Raras, raríssimas são as mulheres verdadeiramente belas, Rev Educ Phys Rio de Janeiro. $1940 ;(41): 16-17$.

37. Le Goff J. “Documento/monumento”. In: Memória-História, Enciclopédia Einaudi, vol. I. Lisboa, Imprensa Nacional - Casa da Moeda, 1985.

38. Almeida MJ. A Liturgia Olímpica. In: Soares CL (organizador) Corpo e história, 3. ed. Campinas, SP: Autores Associados, 2006.

39. Silva ALS. A perfeição expressa na carne: a educação física no projeto eugênico de Renato Kehl-1917 a 1929. [dissertação]. Universidade Federal do Rio Grande do Sul. Programa de Pós-graduação em Ciências do Movimento. Porto Alegre, 2008.

40. Araújo M, Maeso SR. Explorando o eurocentrismo nos manuais portugueses de História. Estudos Sociol Araraquara. 2010;15(28):239-270.

41. Ribeiro MTF, Milane CRS, organizador. Compreendendo a complexidade socioespacial contemporânea: o território como categoria de diálogo interdisciplinar, Salvador: EDUFBA, 2009.

42. Yourcenar M. Memórias de Adriano. Rio de Janeiro, RJ: Nova Fronteira, 1980.

43. Villalba SM. La historia de Antínoo en Fernando Pessoa y en Marguerite Yourcenar: dos grandes de la literatura cara 
a cara, 2002.

44. Giuffré M. Antínoo y la misteriosa pasión de un emperador, 2002.

45. Goellner SV. Bela, maternal e feminina: Imagens da mulher na Revista Educação Physica. Ijuí: Unijuí, 2003.

46. Fotografia. Rev Educ Phys. 1941;(59):11.

47. Nascimento AS. A construção da naçáo arco-íris: problematizando o quesito raça/cor (1936-1960), [dissertação]. Universidade Paulista Júlio de Filho, Programa de Pós-graduação em Sociologia, 2005.

48. Um Pouco de Endocrinologia. Rev Educ Phys Rio de Janeiro. 1940;(40):40-66.

49. Fotografia. Rev Educ Phys Rio de Janeiro. 1940:8.

50. Fotografia. Rev Educ Phys Rio de Janeiro. 1941:11.

51. Seyferth G. Os imigrantes e campanha de nacionalização do Estado Novo. In: Pandolfi D, organizador. Repensando o Estado Novo. Rio de Janeiro: Ed. Fundação Getúlio Vargas, 1999.

52. Munanga K. Rediscutindo a Mestiçagem no Brasil: Identidade nacional versus identidade negra. Belo Horizonte: Autêntica, 2008.

53. Guimarães A. Racismo e Antirracismo no Brasil. São Paulo: 1999.

54. Maio MC. Qual anti-semitismo? Relativizando a questão judaica no Brasil dos anos 30. In: Pandolfi D, organizador. Repensando o Estado Novo. Rio de Janeiro: Ed. Fundação Getúlio Vargas, 1999.

55. Cunha OMG. Sua alma em sua palma: identificando a "raça" e inventando a nação. In: Pandolfi D, organizador. Repensando o Estado Novo. Rio de Janeiro: Ed. Fundação Getúlio Vargas, 1999.

56. Louro GL. Currículo, gênero e sexualidade: o "normal”, o "diferente" e o "excêntrico". In: Goellner SV, Felipe J, Louro GL. Corpo, Gênero e sexualidade: um debate contemporâneo na educação. Petrópolis: Vozes, 2012, v. 1, p. 43-53.

57. Carneiro MLT. Racismo e Imigração: o modelo ideal do homem trabalhador no campo e na cidade (1930-1945). In: Pasetti M. Tra due crisi Urbanizzazione, mutamenti sociali e cultura di massa tra gli anni Trenta e gli anni Settanta. 2013.

58. Santos RV. Mestiçagem, Degeneração e a viabilidade de uma Nação: debates em antropologia física no Brasil (18701930). In: Maio M, Santos RV, organizadores. Raça como questão: História, Ciência e Identidade no Brasil. Rio de Janeiro: Editora da Fiocruz, 2010.

59. Maio MC. "Estoque Semita”: a presença dos judeus em Casa Grande e Senzala. In: Maio M, Santos RV, organizadores. Raça como questão: História, ciência e identidade no Brasil. Rio de Janeiro: Editora da Fiocruz, 2010.

60. Maio MC. Raça, doença e saúde pública no Brasil: um debate sobre o pensamento higienista no Brasil (1870-1930) In: Maio M, Santos RV, organizadores. Raça como questão: História, ciência e identidade no Brasil. Rio de Janeiro: Editora da Fiocruz, 2010.

\begin{tabular}{r|c} 
ENDEREÇO & \\
André Luiz dos Santos Silva & \\
Universidade Federal do Rio Grande do Sul & Submetido: 04/ 10/2018 \\
Rua Felizardo, 50 - Jardim Botânico & Aceito: 11/ 10/2018 \\
$90690-200$ - Porto Alegre - RS - Brasil & \\
E-mail: andrels@ufrgs.br & \\
&
\end{tabular}

